\title{
Effects of prostaglandin analogs on blood flow velocity and resistance in the ophthalmic artery of rabbits
}

\author{
Efeitos dos análogos da prostaglandina na velocidade do fluxo sanguíneo e resistência na \\ artéria oftálmica de coelhos
}

Amália Turner Giannico ${ }^{1}$, Leandro Lima ${ }^{1}$, Gillian C. Shaw ${ }^{2}$, Heloisa H. A. Russ ${ }^{3}$, Tilde Rodrigues Froes ${ }^{1}$, Fabiano Montiani-Ferreira ${ }^{1}$

\begin{abstract}
Purpose: The aim of this study was to investigate the effects of prostaglandin analogs on blood flow in the ophthalmic artery of clinically healthy rabbits.

Methods: Fifty-five clinically healthy New Zealand white rabbits were divided into six groups, and the left eyes were treated for four weeks with the preservative benzalkonium chloride (BAK) only or a topical formulation of different prostaglandin analogs (bimatoprost BAK, tafluprost BAK-free, travoprost BAK, travoprost POLYQUAD, and latanoprost BAK). Color Doppler imaging was performed before and after the treatments. The mean values of the peak systolic velocity (PSV) and end diastolic velocity and the resistive index (RI) were calculated. Statistical analysis was performed to compare the differences pre- and post-treatment for each drug and post-treatment among the drugs.

Results: The prostaglandin analogs did not affect PSV. Bimatoprost BAK, travoprost POLYQUAD, and latanoprost BAK did not change RI. Tafluprost BAK-free and travoprost BAK therapy resulted in similar reductions in $\mathrm{RI}$. No significant differences pre- and post-treatment were found when BAK was administered alone.

Conclusion: The prostaglandin analogs tafluprost BAK-free and travoprost BAK improved blood flow in the ophthalmic artery in healthy New Zealand white rabbits, which suggests that these drugs enhance the prevention of the progression the progression of glaucoma.
\end{abstract}

Keywords: Color Doppler imaging; Orbital hemodynamics; Glaucoma; Oryctolagus cuniculus

\section{RESUMO}

Objetivo: O objetivo deste estudo foi investigar os efeitos dos análogos da prostaglandina (PGAs) no fluxo sanguíneo da artéria oftálmica em coelhos.

Métodos: Cinquenta e cinco coelhos da raça Nova Zelândia clinicamente saudáveis foram divididos em seis grupos para tratamento com formulação tópica de diferentes APGs (bimatoprosta BAK, tafluprosta BAK-free, travoprosta BAK, travoprosta POLYQUAD e latanoprosta BAK) e formulações contendo apenas o conservante cloreto de benzalcônio (BAK). Foi realizada ultrassonografia com Doppler antes e após os tratamentos. Os valores do pico da velocidade sistólica (PSV) e da velocidade diastólica final foram obtidos e o índice de resistência (RI) foi então calculado. A análise estatística foi realizada para comparar as diferenças entre cada droga no pré e pós-tratamento, além das diferenças no pós-tratamento entre as drogas.

Resultados: Estes colírios PGAs não afetaram o PSV. A bimatoprosta com o conservante $B A K$, travoprosta com o conservante POLYQUAD e latanoprosta com o conservante BAK não alteraram o RI. Já o tratamento com tafluprosta sem conservante (BAK-free) e travoprosta com o conservante BAK promoveram redução similar dos valores do RI. Não houve diferença significativa na comparação entre valores pré e pós-tratamento quando BAK foi administrado isoladamente.

Conclusão: Os PGAs tafluprosta BAK-free e travoprosta BAK melhoraram o fluxo sanguíneo na artéria oftálmica em coelhos da raça Nova Zelândia sugerindo que estes medicamentos possam contribuir na prevenção da progressão do glaucoma.

Descritores: Doppler colorido; Hemodinâmica orbital; Glaucoma; Oryctolagus cuniculus

\section{INTRODUCTION}

Glaucoma is a multifactorial disease characterized by progressive optic neuropathy with loss of visual field. Historically, elevated intraocular pressure (IOP) is regarded as the primary cause of glaucomatous optic nerve damage; however, there is now evidence that other factors are involved in the pathogenesis of glaucoma, such as changes in blood flow, perfusion, and oxygen delivery ${ }^{(1)}$. There is compelling accumulated evidence supporting the theory that decreased ocular blood flow contributes to glaucomatous optic neuropathy ${ }^{(1,2)}$. In a model of optic nerve injury, it was demonstrated that alterations of perfusion and oxygen delivery to the retinal ganglion cells may significantly contribute to vision loss ${ }^{(3)}$. Therefore, detailed hemodynamic evaluation of the orbital circulation is needed to better understand this complex disorder.

The hemodynamics of orbital blood vessels can be quantified by color Doppler imaging (CDI), which allows estimations of velocity and resistance to blood flow in unanesthetized subjects. This method has been widely used to study these blood flow parameters in retrobulbar blood vessels in humans and animals $s^{(4-8)}$. The Doppler waveform represents changes in the velocity of the blood flow during the cardiac cycle, and deflections in the late systolic [peak systolic velocity (PSV)] or early diastolic flow [end diastolic velocity (EDV)] are characteristic of high resistance arterial blood flow waveforms ${ }^{(6,9)}$. The resistive index (RI), also known as the Pourcelot ratio, is calculated
Submitted for publication: May 28, 2015

Accepted for publication: October 20, 2015

Universidade Federal do Paraná, Curitiba, PR, Brazil.

Department of Molecular and Comparative Pathobiology, School of Medicine, Johns Hopkins University, Baltimore, MD, USA.

${ }^{3}$ Instituto Graefe de Oftalmologia, Curitiba, PR, Brazil.
Funding: No specific financial support was available for this study.

Disclosure of potential conflicts of interest: None of the authors have any potential conflict of interest to disclose.

Corresponding author: Amália T. Giannico. Rua dos Funcionários, 1.540 - Curitiba, PR - 80035-050 Brazil - E-mail: amaliaturner@uol.com.br

Approved by the following research ethics committee: Universidade Federal do Paraná, protocol \#011/2011. 
from the blood flow velocities. This index, expressed by the formula [(PSV - EDV) / PSV], indicates the downstream resistance in arteries (ranging from 0 to 1, where 0 is no resistance and 1 is the maximum resistance $)^{(9)}$. CDI research has shown that through increased $\mathrm{Rl}$, retrobulbar blood flow is reduced in patients with glaucoma and that there may be a predictive value for the progression of the disease $e^{(10,11)}$. A high Rl value correlates with an increase in vascular resistance, leading to decreased perfusion, which may in turn contribute to glaucomatous optic neuropathy $(2,5,7,9,12,13)$.

Prostaglandin analogs (PGAs) are IOP-lowering agents commonly prescribed in glaucoma treatment. PGAs act primarily by enhancing uveoscleral outflow of aqueous humor; however, PGAs also appear to act on the trabecular meshwork to facilitate aqueous humor outflow through the conventional outflow pathway ${ }^{(14)}$.

The majority of topical treatments for elevated IOP contain a preservative, the most common of which is benzalkonium chloride (BAK), a quaternary ammonium salt. Chronic exposure to BAK has been associated with symptoms of ocular discomfort attributed to BAK-induced instability of the tear film, reduced density of superficial epithelial cells, disruption of corneal epithelial barrier function, and conjunctival inflammation ${ }^{(15,16)}$. These undesirable effects may be reversible in glaucoma patients who are switched to BAK-free medications ${ }^{(15)}$. BAK is absorbed and accumulates in ocular structures involved in glaucoma pathogenesis, but the potential effects of preservatives in the vasculature of the eye are unknown ${ }^{(17)}$.

Considering the growing evidence supporting a vascular pathogenesis for glaucoma, a decrease in blood flow could potentially accelerate disease development. Therefore, in addition to their IOPlowering capabilities, these medications may be detrimental or beneficial to ocular hemodynamics. The purpose of this investigation was to examine the potential effects of topical solutions of PGAs with and without preservatives on the blood flow of the ophthalmic artery $(\mathrm{OA})$ in clinically healthy rabbits.

\section{METHODS}

\section{Animals}

The investigation was carried out using 55 clinically healthy, sixmonth-old New Zealand white rabbits (Oryctolagus cuniculus), with 32 females and 23 males weighing $2.2 \mathrm{~kg}$ to $3.0 \mathrm{~kg}$. The animals were selected randomly from a commercial breeder. All procedures using live rabbits were conducted in accordance with the Federal University of Parana's Animal Use Committee (Curitiba city, Paraná state, Brazil) and with the ARVO Statement for the Use of Animals in Ophthalmic and Vision Research.
The rabbits were housed under a 12:12 hour light: dark cycle for one week prior to and for the duration of the study. Food and water were given ad libitum, and the humidity (70\%) and temperature $\left(22.5^{\circ} \mathrm{C}\right)$ were controlled.

Physical examinations were performed before the ocular examinations to exclude animals with any indications of systemic disease. Rabbits with evidence of ocular or systemic diseases were excluded from this research. To avoid inter-investigator discrepancies, the same masked investigator performed the CDI, and another investigator, who was not masked, instilled the eye drops.

\section{TreatMenTS}

The rabbits received a number from one to 55 and were then divided into six groups using the randomized function in Microsoft Office Excel (Microsoft Office 2007 for Windows). The left eyes were treated daily for four weeks with one drop of topical PGA eye drops applied to the conjunctival fornix. The ophthalmic drugs and numbers of females and males are listed in table 1.

\section{Color Doppler IMAging}

CDI was performed before and after the treatment with eye drops using an ultrasound system (MyLab 30; Esaote, Genova, Italy) equipped with a $12-\mathrm{MHz}$ linear ultrasound transducer. The animals were not anesthetized, and the eye and orbit were imaged with the animal in sternal recumbency. All CDI examinations were performed by the same two people, one of whom restrained the rabbit, while the other performed the imaging. Ultrasound gel was applied to the dorsal region and to the zygomatic arch, and the transducer was gently positioned with minimal pressure in the horizontal plane after instillation of one drop of topical anesthesia (tetracaine ophthalmic drops, Anestalcon ${ }^{\oplus}$, Alcon). The long axis of the transducer was held horizontally between the lateral and medial canthus with the marker pointing nasally (Figure 1A)

We used the muscular cone and power Doppler mode to determine the relative position of the OA. After the detection of the blood flow by the power Doppler, the spectral Doppler sampling volume was placed in the center of the imaged vessel. The OA is readily identifiable by its characteristic dicrotic notch in the Doppler waveform associated with the closure of the aortic valve ${ }^{(5)}$. The ultrasound beam and the OA were parallel, and the sample volume was set at $1 \mathrm{~mm}$ inside the vessel (Figure 1B). The mean values of PSV and EDV from three pulse waveforms were calculated (Figure 1B), and the RI of the blood flow was calculated using the formula [(PSV - EDV) / PSV].

Table 1. Prostaglandin analog eye drops, commercial names, manufacturers, and numbers of female and male New Zealand white rabbits

\begin{tabular}{|c|c|c|c|c|}
\hline \multirow[b]{2}{*}{ Antiglaucomatous eye drops } & \multirow[b]{2}{*}{ Commercial name } & \multirow[b]{2}{*}{ Manufacturer } & \multicolumn{2}{|c|}{ Animals } \\
\hline & & & Female & Male \\
\hline Bimatoprost $0.03 \%{ }^{\mathrm{BAK}}$ & Lumigan & $\begin{array}{l}\text { Allergan Indústria Farmacêutica Ltda. } \\
\text { Guarulhos, SP, Brazil }\end{array}$ & 5 & 5 \\
\hline Tafluprost 0.0015\% ${ }^{\text {BAK-FREE }}$ & Saflutan & $\begin{array}{l}\text { Merck Sharp \& Dohme Ltda., } \\
\text { Guarulhos, SP, Brazil }\end{array}$ & 6 & 4 \\
\hline Travoprost $0.004 \%^{\mathrm{BAK}}$ & Travatan* & $\begin{array}{l}\text { Alcon Laboratórios do Brasil Ltda. } \\
\text { São Paulo, SP, Brazil }\end{array}$ & 5 & 5 \\
\hline Travoprost $0.004 \%{ }^{\text {POLYQUAD }}$ & Travatan* & $\begin{array}{l}\text { Alcon Laboratórios do Brasil Ltda. } \\
\text { São Paulo, SP, Brazil }\end{array}$ & 7 & 3 \\
\hline Latanoprost $0.005 \%{ }^{\mathrm{BAK}}$ & Xalatan & $\begin{array}{l}\text { Pfizer Indústria Farmacêutica } \\
\text { São Paulo, SP, Brazil }\end{array}$ & 6 & 4 \\
\hline Control solution ${ }^{\mathrm{BAK}}$ & BAK & $\begin{array}{l}\text { Benzalkonium chloride } 0.01 \%, \text { "Ophthalmos” Ophthalmic Pharmaceuticals Manipulation } \\
\text { São Paulo, SP, Brazil }\end{array}$ & 3 & 2 \\
\hline
\end{tabular}

${ }^{*}=$ there is no difference in the commercial name between the eye drops Travatan ${ }^{\mathrm{BAK}}$ and Travatan ${ }^{\mathrm{P}}$

$\mathrm{BAK}=$ benzalkonium chloride. 


\section{Statistical analysis}

The Shapiro-Wilk normality test demonstrated that the data errors were normally distributed. The data were statistically analyzed using the computer software StatView (SAS Institute, Cary, NC, USA) ANOVA was used to compare the pre-treatment results to show that the groups were homogeneous. Paired $t$-tests were used to compare the potential differences between pre- and post-treatment results for each drug, and the Tukey-Kramer post hoc test was used to compare potential post-treatment differences among the drugs. P-values of $<0.05$ were considered to be statistically significant.

\section{RESULTS}

The means and standard deviations of the pre- and post-treatment values for RI, PSV, and EDV are presented in table 2. PSV and EDV are expressed in centimeters per second $(\mathrm{cm} / \mathrm{s})$, whereas RI has no units.

No significant differences were found in the pre-treatment PSV, $\mathrm{EDV}$, and $\mathrm{Rl}$ of the left eye of all the rabbits $(P>0.05)$, showing that these parameters were homogeneous amongst the groups before treatment.

No significant differences were found between pre- and posttreatment PSV or EDV in all the animal groups nor for the pre- and post-treatment $\mathrm{RI}$ in the rabbits that received bimatoprost BAK, travoprost POLYQUAD, or latanoprost BAK $(P>0.05)$ (Table 2). However, eyes that received tafluprost BAK-free and travoprost BAK exhibited a significant $R I$ decrease after treatment ( $P=0.003$ and $P=0.005$, respectively) (Table 2). This decrease in RI was similar in magnitude for the two drugs because the post-treatment values in the eyes that received tafluprost BAK-free and travoprost BAK were not significantly different $(P=0.6264)$.

\section{DISCUSSION}

In general, prostaglandins play an important role in the local regulation of blood flow, and both endogenous prostaglandins as well as PGAs can have potent vasodilator effects ${ }^{(18)}$. Previous experiments, both in human and animal models, have reported how PGAs may affect ocular blood flow. Depending on the drug or formulation used, PGAs have been reported to increase, decrease, or not affect ocular blood flow. However, the reports are conflicting, with opposing results in some cases $^{(19,20)}$

In the work presented here, both tafluprost BAK-free and travoprost BAK significantly reduced the $\mathrm{RI}$ of the $\mathrm{OA}$ in rabbits. This decrease in RI can be interpreted as a beneficial effect on ocular blood flow. In primates, chronic optic nerve ischemia has been shown to induce retinal ganglion cell loss independently of high $1 O P^{(3)}$. Consequently, this reduction of the RI of the OA could also be helpful in glaucoma treatment, by potentially preventing retinal ganglion cell
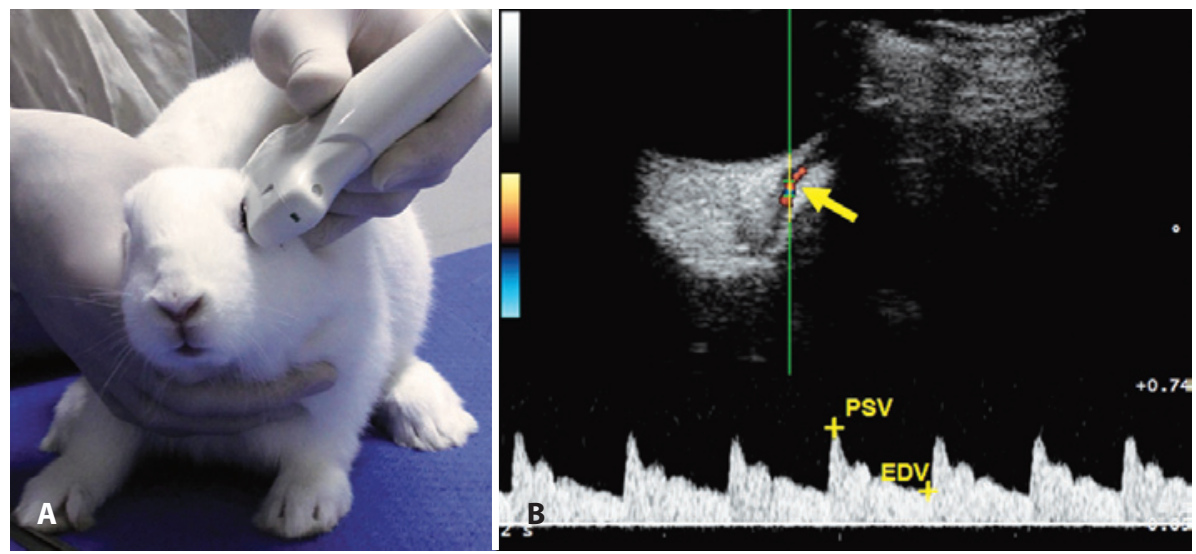

$\mathrm{PSV}=$ peak systolic velocity; $\mathrm{EDV}=$ end diastolic velocity

Figure 1. (A) Image of a New Zealand white rabbit during the ultrasound exam. The transducer was positioned in the horizontal plane, with the long axis of the transducer held parallel with a line connecting the medial and lateral canthus, and the marker pointing nasally. (B) The top panel shows an image of retrobulbar color Doppler imaging and pulse waveform with dicrotic notches showing blood flow velocities in a rabbit's ophthalmic artery. Blood flow toward the ultrasound transducer was encoded in red by the power Doppler mode. The ophthalmic artery was detected and the spectral Doppler sampling volume (gate of $1 \mathrm{~mm}$ ) was placed in the center and parallel to the imaged vessel (arrow). The bottom panel is a pulse waveform showing relative blood flow velocities.

Table 2. Results of retrobulbar blood flow velocity $(\mathrm{cm} / \mathrm{s})$ and resistive index pre- and post-treatment with prostaglandin analog eye drops as measured with color Doppler imaging in the ophthalmic artery of New Zealand white rabbits

\begin{tabular}{|c|c|c|c|c|c|c|c|c|c|}
\hline \multirow[b]{2}{*}{ Antiglaucomatous eye drops } & \multicolumn{3}{|c|}{ PSV } & \multicolumn{3}{|c|}{ EDV } & \multicolumn{3}{|c|}{$\mathbf{R I}$} \\
\hline & Pre & Post & $P$-value & Pre & Post & $P$-value & Pre & Post & $P$-value \\
\hline Bimatoprost ${ }^{\mathrm{BAK}}$ & $31.19 \pm 4.88$ & $34.89 \pm 7.17$ & 0.194 & $8.21 \pm 2.89$ & $9.94 \pm 3.38$ & 0.234 & $0.74 \pm 0.08$ & $0.74 \pm 0.10$ & 0.941 \\
\hline Tafluprost ${ }^{\text {BAK-FREE }}$ & $36.64 \pm 5.50$ & $30.03 \pm 8.92$ & 0.061 & $9.80 \pm 2.81$ & $11.22 \pm 4.71$ & 0.424 & $0.73 \pm 0.07$ & $0.63 \pm 0.07$ & $0.003^{*}$ \\
\hline Travoprost ${ }^{\text {BAK }}$ & $29.21 \pm 5.79$ & $31.91 \pm 11.14$ & 0.548 & $8.49 \pm 3.45$ & $13.62 \pm 6.55$ & 0.066 & $0.71 \pm 0.09$ & $0.59 \pm 0.07$ & $0.005^{*}$ \\
\hline Travoprost ${ }^{\text {POLYQUAD }}$ & $34.81 \pm 9.34$ & $33.01 \pm 10.44$ & 0.689 & $9.68 \pm 3.46$ & $10.48 \pm 5.29$ & 0.694 & $0.72 \pm 0.05$ & $0.68 \pm 0.09$ & 0.244 \\
\hline Latanoprost ${ }^{\mathrm{BAK}}$ & $34.57 \pm 6.23$ & $30.07 \pm 8.57$ & 0.196 & $10.94 \pm 3.51$ & $9.20 \pm 4.73$ & 0.362 & $0.69 \pm 0.06$ & $0.70 \pm 0.06$ & 0.551 \\
\hline Control solution ${ }^{\text {BAK }}$ & $33.88 \pm 7.37$ & $34.26 \pm 11.95$ & 0.953 & $8.10 \pm 1.67$ & $9.10 \pm 2.84$ & 0.517 & $0.75 \pm 0.07$ & $0.73 \pm 0.04$ & 0.552 \\
\hline
\end{tabular}

Values are the mean \pm standard deviation.

$\mathrm{PSV}=$ peak systolic velocity; $\mathrm{EDV}=$ end diastolic velocity; $\mathrm{RI}=$ resistive index; $\mathrm{BAK}=$ benzalkonium chloride.

$* P<0.05$, paired $t$-test between pre- and post-treatment results. 
death. Although these two formulations decreased the RI to similar extents, other factors need to be considered when choosing which one to prescribe, such as which one is more effective for decreasing $I O P$ and, in this specific case, whether the presence of a preservative is detrimental to each patient in question. The presence of preservatives in topical antiglaucoma drug formulations is currently under scrutiny ${ }^{(21)}$. Chronic exposure to the preservative BAK has been associated with ocular discomfort, causing changes in the tear film, cornea (including the corneal epithelium), and conjunctiva ${ }^{(15,16)}$.

No effects on CDI parameters were found for topical bimatoprost BAK, travoprost POLYQUAD, or latanoprost BAK. Some research has also revealed no changes in the blood flow in the OA in humans and rabbits in response to PGAs, although some PGAs show good results in other vascular beds, such as on the optic nerve head and in the central retinal artery ${ }^{(20,22-24)}$. Nevertheless, our research showed that the results with travoprost are controversial. Interestingly, formulation of this drug with two different preservatives showed disparate results, and more studies are needed to confirm the effect of this drug on Rl. Other research groups have shown that travoprost is effective for improving blood flow, as found in the present study with travoprost BAK ${ }^{(25-27)}$. Further, in the present research, travoprost with $B A K$ as a preservative significantly decreased RI, while travoprost with POLYQUAD did not; therefore, the preservative BAK may have some effect in this instance. Little is known about the long-term effects of different preservatives concerning their penetration and distribution in the eye, but it is recognized that BAK is itself absorbed and accumulates in ocular surface structures as well as in deeper structures involved in glaucoma ${ }^{(17)}$. Interestingly, our findings suggest that the combination of PGA with BAK decreases RI, ultimately improving ocular blood flow. Despite this RI alteration observed in the travoprost with BAK group, no significant decreases in RI were found in the other groups receiving drugs preserved with BAK or groups receiving only BAK. It is possible that BAK specifically and synergistically enhances the effect of travoprost by an as-yet-unknown mechanism. Nevertheless, some investigators have argued that eye drops formulated with preservatives other than BAK or with no preservatives demonstrate little or no ocular toxicity, and may always be preferred(28).

Few studies have evaluated the effect of tafluprost on ocular circulation. In the present study, a significant decrease was found in the $\mathrm{Rl}$ of the OA of rabbits, and similar results have also been found in the optic nerve and retinal circulation in rabbits, cats, and humans ${ }^{(27,29,30)}$.

In the present study, both eyes were analyzed, but the eye drops were instilled in only one of the eyes. The main advantage of using the fellow eye as a control is that the experimental eye and the control eye are both in the same animal, therefore allowing direct comparison, balancing out any variations of the treatment and control groups.

A limitation of our study is that no glaucomatous eyes were evaluated. Healthy eyes, without increased IOP, may facilitate changes in Doppler parameters. Thus, we suggest that further studies be carried out in rabbits with induced glaucoma to assess whether the changes would be similar to those found in the present study.

Our study reveals the effect of different PGAs used to treat glaucoma on OA blood flow in healthy New Zealand white rabbits. Further studies on human patients and patients with glaucoma (humans and animals) are necessary to establish the effects of each treatment and to assess whether improvement of retrobulbar blood flow enhance the prevention of the progression of this disease.

\section{REFERENCES}

1. Drance S, Anderson DR, Schulzer M. Risk factors for progression of visual field abnormalities in normaltension glaucoma. Am J Ophthalmol. 2001;131(6):699-708.

2. Carter CJ, Brooks DE, Doyle DL, Drance SM. Investigations into a vascular etiology for low-tension glaucoma. Ophthalmology. 1990;97(1):49-55.
3. Cioffi GA. Ischemic model of optic nerve injury. Trans Am Ophthalmol Soc. 2005; 103:592-613.

4. Galassi F, Nuzzaci G, Sodi A, Casi P, Cappelli S, Vielmo A. Possible correlations of ocular blood flow parameters with intraocular pressure and visual-field alterations in glaucoma: a study by means of color Doppler imaging. Ophthalmologica. 1994; 208(6):304-8.

5. Williamson $\mathrm{TH}$, Harris A. Color doppler ultrasound imaging of the eye and orbit. Surv Ophthalmol. 1996:40(4):255-67.

6. Gelatt-Nicholson KJ, Gelatt KN, MacKay E, Brooks DE, Newell SM. Doppler imaging of the ophthalmic vasculature of the normal dog: blood velocity measurements and reproducibility. Vet Ophthalmol. 1999;2(2):87-96.

7. Liu JH, Li R, Nelson TR, Weinreb RN. Resistance to blood flow in the rabbit ophthalmic artery after topical treatment with timolol. J Ocul Pharmacol Ther. 2007;23(2):103-9.

8. Yang Q, Shen J, Guo W, Wen J, Wang Z, Yu D. Effect of acute intraocular pressure elevation on blood flow velocity and resistance in the rabbit ophthalmic artery. Vet Ophthalmol. 2011;14(6):353-7.

9. Pourcelot L. Velocimetrie ultrasonore doppler. Séminaire INSERM. Paris, France: Editions INSERV; 1974. p.213-40.

10. Martinez A, Sanchez M. Predictive value of colour Doppler imaging in a prospective study of visual field progression in primary open-angle glaucoma. Acta Ophthalmol Scand. 2005;83(6):716-22.

11. Zeitz O, Galambos P, Wagenfeld L, Wiermann A, Wlodarsch P, Praga R, et al. Glaucoma progression is associated with decreased blood flow velocities in the short posterior ciliary artery. Br J Ophthalmol. 2006;90(10):1245-8.

12. Hayreh SS, Revie IH, Edwards J. Vasogenic origin of visual field defects and optic nerve change in glaucoma. Br J Ophthalmol. 1970;54(7):461-72.

13. Pozniak MA, Kelcz F, Stratta RJ, Oberley TD. Extraneous factors affecting resistive index Invest Radiol. 1988;23(12):899-904.

14. Schachtschabel U, Lindsey JD, Weinreb RN. The mechanism of action of prostaglandins on uveoscleral outflow. Curr Opin Ophthalmol. 2000;11:112-5.

15. Pisella PJ, Pouliquen P, Baudouin C. Prevalence of ocular symptoms and signs with preserved and preservative free glaucoma medication. Br J Ophthalmol. 2002;86:418-23.

16. Ishibashi T, Yokoi N, Kinoshita S. Comparison of the short-term effects on the human corneal surface of topical timolol maleate with and without benzalkonium chloride. J Glaucoma 2003;12:486-90.

17. Champeau EJ, Edelhauser HF. The effect of ophthalmic preservatives on the ocular surface: conjunctival and corneal uptake and distribution of Benzalkonium chloride and chlorhexidine digluconate. In: Holly FJ, editor. The Preocular Tear Film in Health, Disease and Contact Lens Wear. Lubbock, TX: Dry eye Institute, Inc.; 1986.

18. Kimura T, Yoshida Y, Toda, N. Mechanisms of relaxation induced by prostaglandins in isolated canine uterine arteries. Am J Obstet Gynecol. 1992;67:1409-16.

19. Ishikawa H, Yoshitomi T, Mashimo K, et al. Pharmacological effects of latanoprost, prostaglandin E2, and F2alpha on isolated rabbit ciliary artery. Graefes Arch Clin Exp Ophthalmol. 2002;240:120-5.

20. Akaishi T, Kurashima H, Odani-Kawabata N, et al. Effects of repeated administrations of tafluprost, latanoprost, and travoprost on optic nerve head blood flow in conscious normal rabbits. J Ocul Pharmacol Ther. 2010;26:181-6.

21. Stalmans I, Sunaric Mégevand G, Cordeiro MF, et al. Preservative-free treatment in glaucoma: who, when, and why. Eur J Ophthalmol. 2013;23:518-25.

22. Alagoz G, Gürel K, Bayer A, Serin D, Celebi S, Kukner S. A comparative study of bimatoprost and travoprost: effect on intraocular pressure and ocular circulation in newly diagnosed glaucoma patients. Ophthalmologica. 2008;222:88-95.

23. Harris A, Garzozi HJ, McCranor L, Rechtman E, Yung CW, Siesky B. The effect of latanoprost on ocular blood flow. Int Ophthalmol. 2009:29:19-26.

24 García-Pérez JL, Puerto-Hernández B, Rebolleda Fernández G, Muñoz-Negrete FJ González-Gordaliza C. Evaluation of the effect of bimatoprost/timolol fixed combination on ocular blood flow in patients with ocular hypertension using colour Doppler imaging. Preliminary study. Arch Soc Esp Oftalmol. 2010;85:131-7.

25. Koz OG, Ozsoy A, Yarangumeli A, Kose SK, Kural G. Comparison of the effects of travoprost, latanoprost and bimatoprost on ocular circulation: a 6-month clinical trial. Acta Ophthalmol Scand. 2007;85:838-43.

26. Ohashi M, Mayama C, Ishii K, Araie M. Effects of topical travoprost and unoprostone on optic nerve head circulation in normal rabbits. Curr Eye Res. 2007;32:743-9.

27. Kurashima H, Watabe H, Sato N, Abe S, Ishida N, Yoshitomi T. Effects of prostaglandin $F(2 a)$ analogues on endothelin-1-induced impairment of rabbit ocular blood flow: comparison among tafluprost, travoprost, and latanoprost. Exp Eye Res. 2010;91:853-9.

28. Ammar DA, Noecker RJ, Kahook MY. Effects of benzalkonium chloride-preserved, polyquad- preserved, and sofZia-preserved topical glaucoma medications on human ocular epithelial cells. Adv Ther. 2010;27:837-45.

29. Izumi N, Nagaoka T, Sato E, Mori F, Takahashi A, Sogawa K, Yoshida A. Short-term effects of topical tafluprost on retinal blood flow in cats. J Ocul Pharmacol Ther. 2008:24:521-6.

30. Tsuda S, Yokoyama Y, Chiba N, Aizawa N, Shiga Y, Yasuda M, Yokokura S, Otomo T, Fuse $\mathrm{N}$, Nakazawa T. Effect of topical tafluprost on optic nerve head blood flow in patients with myopic disc type. J Glaucoma 2013:22:398-403. 